\title{
Correction: Rodionov, A.V., et al. Intragenomic Polymorphism of the ITS 1 Region of 35S rRNA Gene in the Group of Grasses with Two-Chromosome Species: Different Genome Composition in Closely Related Zingeria Species. Plants 2020, 9, 1647
}

\author{
Alexander V. Rodionov ${ }^{1,2}$, Alexander A. Gnutikov $\left.{ }^{3}{ }^{(}\right)$, Nikolai N. Nosov ${ }^{1}$, Eduard M. Machs ${ }^{1}$, \\ Yulia V. Mikhaylova ${ }^{1}$ (D), Victoria S. Shneyer ${ }^{1, *}$ and Elizaveta O. Punina ${ }^{1}$ (D) \\ 1 Laboratory of Biosystematics and Cytology, Komarov Botanical Institute of the Russian Academy of Sciences, \\ 197376 St. Petersburg, Russia; avrodionov@binran.ru (A.V.R.); NNosov@binran.ru (N.N.N.); \\ emachs@binran.ru (E.M.M.); YMikhaylova@binran.ru (Y.V.M.); EPunina@binran.ru (E.O.P.) \\ 2 Biological Faculty, St. Petersburg State University, 199034 St. Petersburg, Russia \\ 3 Department of Genetic Resources of Oat, Barley, Rye, N.I. Vavilov Institute of Plant Genetic Resources (VIR), \\ 190000 St. Petersburg, Russia; a.gnutikov@vir.nw.ru \\ * Correspondence: shneyer@binran.ru
}

Citation: Rodionov, A.V.; Gnutikov, A.A.; Nosov, N.N.; Machs, E.M.; Mikhaylova, Y.V.; Shneyer, V.S.; Punina, E.O. Correction: Rodionov, A.V., et al. Intragenomic

Polymorphism of the ITS 1 Region of 35S rRNA Gene in the Group of Grasses with Two-Chromosome Species: Different Genome Composition in Closely Related Zingeria Species. Plants 2020, 9, 1647. Plants 2021, 10, 463. https://doi.org/ $10.3390 /$ plants 10030463

Received: 28 December 2020

Accepted: 26 January 2021

Published: 1 March 2021

Publisher's Note: MDPI stays neutral with regard to jurisdictional claims in published maps and institutional affiliations.

Copyright: (c) 2021 by the authors. Licensee MDPI, Basel, Switzerland. This article is an open access article distributed under the terms and conditions of the Creative Commons Attribution (CC BY) license (https:// creativecommons.org/licenses/by/ $4.0 /)$.
The authors wish to make the following corrections to their paper [1].

In Section 2. (Results), Paragraph 2, Page 3 of 11: "The sequence of Catabrosella variegata subsp. variegata KM523774 (Adygea, Russia, voucher "US:Soreng et al. 8040") [28] was also located in this network. The observed position of KM523774 could be explained by the misidentification of voucher specimen, and the specimen should be identified as $\mathrm{C}$. araratica." should be deleted.

In Figure 1, Catabrosella variegata KM523774 should be replaced by Catabrosella araratica HE802183.

In Figure 2, Catabrosella variegata KM523774 should be replaced by Catabrosella araratica HE802183.

In Figure 3, Catabrosella variegata KM523774 should be deleted.

In Supplementary Table S1, line "C. variegata KM523774 Adygea, Russia [8]" and reference 8: "8 Soreng, R.J.; Gillespie, L.J.; Koba, H.; Boudko, E.; Bull, R.D. Molecular and morphological evidence for a new grass genus, Dupontiopsis (Poaceae tribe Poeae subtribe Poinae s.l.), endemic to alpine Japan, and implications for the reticulate origin of Dupontia and Arctophila within Poinae s.l. J. Syst. Evol. 2015, 53, 138-162, doi:10.1111/jse.12146." should be deleted.

In Supplementary Table S1, references 9 and 10 should be considered as references 8 and 9 , respectively.

The changes do not affect the main results and conclusion of the paper. We would like to apologize for any inconvenience caused to readers. We would like to apologise to Prof. Robert Soreng, whom we improperly mentioned in the text. The manuscript will be updated and the original will remain available on the article webpage.

\section{Reference}

1. Rodionov, A.V.; Gnutikov, A.A.; Nosov, N.N.; Machs, E.M.; Mikhaylova, Y.V.; Shneyer, V.S.; Punina, E.O. Intragenomic Polymorphism of the ITS 1 Region of 35S rRNA Gene in the Group of Grasses with Two-Chromosome Species: Different Genome Composition in Closely Related Zingeria Species. Plants 2020, 9, 1647. [CrossRef] [PubMed] 